\title{
DESCONSTRUÇÃO CIENTÍFICA NA DUPLA RUPTURA - UMA ANÁLISE DE DIADORIM E A APROXIMAÇÃO CIÊNCIA/SOCIEDADE
}

\author{
SCIENTIFIC DECONSTRUCTION IN DOUBLE RUPTURE: THE ANALYSIS OF \\ DIADORIM AND THE SCIENCE/SOCIETY APPROACH.
}

\section{LA DECONSTRUCCIÓN CIENTÍFICA EN LA DOBLE RUPTURA: UN ANÁLISIS DEL DIADORIN Y LA APROXIMACIÓN CIENCIA/SOCIEDADE}

\author{
Érica Masiero Nering \\ Doutoranda, Universidade de São Paulo \\ nering@usp.br
}

\begin{abstract}
Resumo
O artigo visa a discutir a produção de hipermídia como uma tendência de linguagem com funções educativas ou de divulgação científica. No contexto da “ciência pós-moderna” de Santos (1989) a hipermídia apresenta elementos que propiciam a desconstrução hermenêutica para a dupla ruptura epistemológica proposta pelo autor. Entende-se que a utilização da linguagem híbrida e da interação são potenciais no sentido de permitir à ciência um desnivelamento entre os denominados “saber científico” e "senso comum”. Para exemplificar, analisou-se "DiadorimHistória Local nos Processos de Alfabetização de Crianças, Jovens e Adultos do Município de Diadema” (Iokoi, 2002), hipermídia produzida por uma equipe interdisciplinar de pesquisadores com vistas à utilização de material acadêmico na educação básica.
\end{abstract}

Palavras-chave: Comunicação. Hipermídia. Dupla ruptura epistemological.

\begin{abstract}
The paper intends to discuss the hypermedia production as a language tendency with educational or science dissemination functions. In the "post-modern science" context defended by Santos (1989) hypermedia has elements for the hermeneutic deconstruction of science for double rupture, proposed by the author. We understand that the hybrid language and interaction uses are potential in the way of allowing to science a levelness between "science knowledge" and "common sense". To exemplify, we analyzed "Diadorim- Local History in alphabetization process of Children, Young and Adults of Diadema city” (Iokoi, 2002), hypermedia produced by an interdisciplinary research group intending to use academic material for basic education.
\end{abstract}

Esta obra está licenciada sob uma Licença Creative Commons 
Keywords: Communication. Hypermedia. Double epistemological rupture.

\section{Resumen}

El artículo tiene como objetivo analizar la producción de hipermedia como lengua tendencia para las funciones de carácter científico o educativo. En el contexto de la "ciencia posmoderna" Santos (1989) presentamos los elementos de la hipermedia que proporcionan la deconstrucción de la doble ruptura epistemológica hermenéutico propuesto por el autor. Se entiende que el uso de lenguaje híbrido y la interacción son potencial de permitir a la ciencia una desviación entre el llamado "conocimiento científico" y "sentido común." Para ilustrar, se analizaron "DiadorinHistoria Local procesos de alfabetización en los niños, jóvenes y adultos Diadema" (Iokoi, 2002), hipermedia producida por un equipo interdisciplinario de investigadores con miras a la utilización de material académico en educación básica.

Palabras Clave: Comunicación. Hipermedia. Doble ruptura epistemológica.

\section{INTRODUÇÃO}

\subsection{Ciência em Hipermídia: um admirável mundo novo?}

Ciência? O Selvagem franziu a testa. Conhecia a palavra. O que significava exatamente, porém, ele não o sabia. [...] a ciência era uma coisa com a qual se faziam helicópteros, uma coisa que fazia com que a gente risse das Danças do Trigo, uma coisa que impedia de ter rugas e de perder os dentes. Fez um esforço desesperado para compreender o que o Administrador queria dizer.

- Sim- continuou Mustapha Mond-, essa é outra parcela no custo da estabilidade. Não é somente a arte que é incompatível com a felicidade, também o é a ciência. Ela é perigosa; temos de mantê-la cuidadosamente acorrentada e amordaçada.

- O que? - exclamou Helmoltz, assombrado- Mas nós vivemos repetindo que a ciência é tudo. É um lugar-comum hipnopédico.

- Três vezes por semana, dos treze aos dezoito anos- recitou Bernard.

- E toda a propaganda da ciência que fazemos no colégio...

- Sim, mas que espécie de ciência? - perguntou sarcasticamente Mustapha Mond- Os senhores não receberam instrução científica, de modo que não têm condições de julgar. (HUXLEY, 1932). 
Um membro comum da sociedade, um esclarecido e o cientista: são o Selvagem, Helmoltz e Mustapha Mond, na fábula científica do ano de 1932, criada por Aldous Huxley. Na história de Admirável Mundo Novo, o autor cria um mundo imaginário, uma perspectiva pessimista a respeito do futuro que as inovações tecnológicas nos levariam. Nela, as pessoas são condicionadas a viver sob regras pré-determinadas por meio de um condicionamento biológico e psicológico que as levam a viver em uma harmonia imposta por treinamento ou pelo consumo da droga "soma”, que impede os cidadãos de passarem por qualquer questionamento sobre a sociedade em que vivem. Essas pessoas também são educadas em “castas” de trabalhadores desde o nascimento por meio de ideias hipnopédicas - frases repetidas indefinidamente durante a vida, que determinam as verdades aceitas pelas pessoas. A característica principal é a incapacidade crítica desses cidadãos. Uma verdadeira condenação do autor à sociedade do presente da década de 30, com um mote futurístico, mas que continua extremamente atual.

A ciência, como conhecimento, transformou-se em sabedoria de poucos, limitou-se àqueles privilegiados que, ao romper com aquelas barreiras que levam às universidades, têm acesso a uma educação voltada aos paradigmas da produção científica. É o que o Thomas Kuhn (2009) chamou de educação para a ciência normal, ou a tal da instrução científica que Mustapha Mond cita. Já a maioria da população reproduz a ideia hipnopédica de que a ciência é tudo, é importante, é essencial. Mas, sem saber exatamente como ela funciona, a que se deve. Sabemos apenas que ela "ri das Danças do Trigo", ou, não dialoga com os saberes populares. E entendemos aqui que este é o grande problema do por que da cultura científica não ser um valor compreensível.

Acreditamos, nesse contexto, que as possibilidades advindas da cibercultura podem e deverão auxiliar na linguagem científica contemporânea para uma aproximação com a sociedade, uma vez que suas competências comunicativas na contemporaneidade constroem-se ciberculturalmente (Corrêa, 2010, p.9). Falamos de computadores, de comunicação, de digital e da hipermídia. São ferramentas potenciais para tirar a ciência, e qualquer assunto que assusta e exclui não-especialistas, da condição de ideia hipnopédica.

O universo do digital, das redes, está tão inserido em nosso cotidiano, que fez até mesmo emergir uma nova cultura. Segundo Corrêa (2010), estamos vivendo mais um ciclo histórico- 
social de mudanças e transformações que denominamos por cibercultura: uma situação que parte de reconstruções e retomadas de ciclos anteriores. "[A] cibercultura pode ser entendida como uma agregação de conhecimentos de diferentes origens e ordens, buscando traduzir um ponto de inflexão da sociedade contemporânea” (Corrêa, 2010, p.19).

Santaella (2005) coloca o processo de digitalização na base dessa mudança cultural. Ela propicia a universalização da linguagem, uma vez que toda e qualquer fonte de informação pode ser homogeneizada em cadeias sequenciais de 0 e 1 (Santaella, 2005, p.389). São os bits.

Além da digitalização da linguagem, a digitalização possui pelo menos dois outros méritos: de um lado, a compressão de dados, fenômeno suplementar que permite, de maneira cada vez menos onerosa, estocar e fazer circular uma quantidade enorme de informação; de outro lado, a independência da informação digital em relação ao meio de transporte. Sua qualidade permanece perfeita seja ela transmitida via fio de telefone, onda de rádio, satélite de televisão, cabo, etc. (Santaella, 2005, p.389).

Assim, a digitalização tem sido a base de mudanças culturais que vêm ocorrendo no contexto cibercultural. A facilidade de circulação da informação e de todos os tipos de dados permite a troca e disponibilização via rede ou mídias fechadas, como o CD-ROM, de arquivos de imagens, vídeos, sons, texto. Nesse sentido, a ciência encontra um ambiente profícuo, uma vez que ela se constrói pela troca de experiências e dados entre cientistas, sejam por trocas de correspondências, publicações, gráficos e resultados.

Um aspecto importante dessa mudança está na convergência de mídias e na hibridização das tecnologias. Por exemplo, um aparelho antes destinado a somente fazer ligações telefônicas, passa a ser também receptor de rádio, televisão e internet, como são os chamados smartphones. Isso tudo, segundo Santaella (2005), é apenas um epifenômeno no contexto da pós-modernidade comunicacional: a cultura do disponível e do efêmero propiciada pelas máquinas fotocopiadoras ajudou a intensificar essa convergência que deu origem à grande hibridização de linguagens, conjuntura que fez surgir a nova linguagem: a hipermídia.

A autora afirma que, tendo em vista a acelerada expansão da hipermídia como linguagem nos últimos anos, o papel desempenhado por ela na cultura que está emergindo é ainda 
incalculável, mas sugere que essa será a base de uma revolução comparável àquela que ocorreu com a multiplicação crescente da cultura livresca após a invenção de Gutemberg, o mesmo livro que está longe de ser um mero objeto, mas que "foi instaurador de formas de cultura que lhe são próprias, que incluíram desde o Renascimento, nada menos do que o desenvolvimento da ciência moderna e a constituição do saber universitário” (Santaella, 2004, p.15).

Além da linguagem híbrida, a hipermídia pressupõe a interação ativa do leitor imersivo: não é possível consumir o conteúdo de uma hipermídia sem interagir com ela, sua estrutura deve obrigatoriamente ser manuseada e ao leitor é dada a função de escolha pelo caminho a seguir no labirinto. Com a diferença de que não há caminho certo ou errado para sair dali; aliás, sair não é o principal objetivo e o perder-se faz parte do encontrar-se. Essa característica foi denominada de arquiteturas líquidas, como explica:

Essa expressão foi cunhada por Marcos Novak (1993) para se referir à modelização líquida da informação, aos dados fluidos, moventes e plásticos acessíveis ao usuário na medida em que este navega na hipermídia, interagindo com os nós e nexos de um roteiro multilinear, multi-sequencial, multi-sígnico (palavras, imagens, textos, documentos, sons, ruídos, música, vídeo) e labiríntico que o usuário, ele próprio, ajudou interativamente a construir. Ao escolher um percurso, entre muitas possibilidades, o leitor estabelece sua co-participação na produção das mensagens. (Santaella, 2005, p.392-393).

Co-participação, nesse sentido, significa que o conteúdo está ali, mas cabe ao leitor participar ativamente da navegação e fazer seu próprio caminho ao construir uma linha própria de pensamento e, consequentemente, uma maneira absolutamente própria e participativa de compreensão do conhecimento adquirido.

Isso tudo é possibilitado pelo formato hipertexto, que oferece à hipermídia uma organização reticular em que é possível armazenar informações - indefinidamente - e organizá-las hipertextualmente por meio de nós que rompem com qualquer estrutura linear que se queira fornecer ao texto. Assim, por meio da interação do leitor é possível criar diversas formas de lidar com o material, o que faz desse leitor não apenas consumidor, mas também produtor, ou até mesmo co-autor. É nesse sentido, portanto, que o leitor passa cada vez mais a ter importância. Ele 
passa a ser o ponto central do conteúdo, produzido diante da expectativa de um leitor satisfeito: ele decide qual caminho é o ideal para ser seguido, qual informação deve ser lida antes ou depois e como aquilo deve ser apreendido. A palavra escrita é muito mais imperativa, enquanto o som e a imagem abrem-se para um universo de significados.

\section{COMUNICAÇÃO CIENTÍFICA NO CONTEXTO DIGITAL}

A instituição da palavra impressa como paradigma dominante na comunicação, e também na comunicação científica, influenciou no problema do afastamento entre a sociedade e a cultura científica. Compreendemos aí dois processos que ocorrem conjuntamente: o primeiro deles a privação do "homem ordinário” de participar - passiva ou ativamente - de observações científicas; e o segundo o advento da era impressa, que instituiu a técnica da escrita como meio elementar de compreensão do mundo, excluindo dessas questões, comunidades essencialmente orais, por exemplo.

McLuhan (1964) em seu Os meios de comunicação como extensão do homem já discute a questão do letramento da sociedade e as perdas ao sairmos da cultura tribal e oral para a alfabetizada: nossa razão foi por muito tempo limitada e unificou nossos sentidos para associarem a racionalidade ao escrito. E talvez os meios eletrônicos surjam para recuperarmos a nossa racionalidade sensória, passando do que Flusser (2007) denominou pela sociedade da "linha" (linear, escrita, impressa), para a sociedade em "superfície”, que parte do audiovisual, “O próximo passo é transferir a consciência do mundo para o computador” (McLuhan, 1964, p.81). Galison et al (2005) também discutem essa questão ao falar sobre a experiência da Wall of Science ${ }^{1}$, produzida com filmes do curso ministrado na Universidade de Harvard “Filming Science":

Our medium has been print, in all of its variations. But now that we are increasingly, interested in process, in the materiality of science, we believe it is

\footnotetext{
1 “Paredão da Ciência”, uma parede constituída de telas em que se transmitem filmes produzidos com o tema da cultura científica.
} 
high time to make use of digital technologies to explore the science-making process where it is done: on laboratory, floors and theorists' blackboards and at scientists field stations ${ }^{2}$. (Galison; Moss, 2005, p.332)

O desenvolvimento da imprensa permitiu uma maior possibilidade de divulgação das ideias, ao mesmo tempo em que limitou seu acesso àqueles que eram capazes de compreender seus escritos. Segundo Flusser (2007, p.103), o desenvolvimento da imprensa vulgarizou o alfabeto e transformou mais agudamente, a partir do século XIX, a consciência histórica em razão da linearidade o clima fundamental da nossa sociedade. Foi a imprensa que deu subsídios para o desenvolvimento da ciência moderna sob a égide da escrita, já no século XVII quando, segundo Foucault (2007):

O primado da escrita está suspenso. Desaparece então essa camada uniforme onde se entrecruzam indefinidamente o visto e o lido, o visível e o enunciável. As coisas e as palavras vão separar-se. O olho será destinado a ver e somente a ver; o ouvido somente a ouvir. O discurso terá realmente por tarefa dizer o que é, mas não será mais nada do que ele diz. (Foucault, 2007, p.59)

O homem acostumado ao saber do cotidiano, ao saber do diálogo em praças públicas, voltou-se ao saber em linha cartesiana em que “as linhas são discursos de pontos, e que cada ponto é um símbolo de algo que existe lá fora no mundo (um “conceito”)” (Flusser, 2007, p.103).

A adaptação do pensamento à coisa, como definiu Flusser, é superado por uma adequação da coisa ao pensamento. Passamos por um processo histórico de adequação do nosso intelecto à imposição de uma estrutura linear, em prol de uma racionalidade que se fecha em si mesma. Agora, temos a possibilidade de adequar as coisas à forma do nosso pensamento, e o meio para isso passa pela técnica. Essa questão é absolutamente contemporânea. Diríamos, sobre as teorias da comunicação, que partimos de uma relação sujeito-objeto da mídia como extensão do homem (McLuhan, 1964) para um processo de hibridização dos sentidos pelas tecnologias. As novas

\footnotetext{
2 “Nosso meio tem sido o impresso, em todas as suas variações. Mas agora que nós estamos cada vez mais interessados nos processos, na materialidade da ciência, nós acreditamos que é tempo de fazer uso das tecnologias digitais para explorar o processo de fazer-ciência onde ele é feito: no laboratório, no chão e na mesa dos teóricos e em suas estações de trabalho.”
} 
gerações aprenderão a pensar e a conceitualizar por meio de vídeos, imagens e som, mas também texto: o hipertexto. Flusser, ainda ao pensar sobre as mídias de comunicação de massa, e não sobre o digital, chama esse processo de “adequação do pensamento em superfície à coisa”. É como Ted Nelson previu em seu artigo “Literacy Machines”:

Imaginem uma nova forma de acessibilidade e emoção capaz de desbancar a narcose do vídeo que agora recobre o nosso país como uma neblina. Imaginem uma nova literatura libertária com explicações alternativas, de modo que cada um possa escolher o caminho ou enfoque que mais lhe convenha, com ideias acessíveis e interessantes para todo o mundo, para que a experiência humana possa gozar de novas liberdades e riquezas; imaginem um renascer das letras. (Nelson apud Bairon, 2007, p.59).

Se o pensamento imagético está começando a pensar conceitos, a ciência deverá em breve tomar partido dessa nova linguagem para acompanhar a civilização que está emergindo.

Michel Foucault, ao falar sobre representação, a aborda diante da filosofia cartesiana, que representa o "pensamento clássico excluindo a semelhança como experiência fundamental e forma primeira do saber” (2002, p.71). A tradição moderna exclui a forma de ver o saber em sua essência de representação. Mas, com a crise do método científico moderno, emergimos em uma época dos sentidos “enganadores” da racionalidade: o erro passa a ser um perigo para o qual estamos abertos, nos abrimos para as metáforas, as analogias, as comparações (Foucault, 2002, p.70). E as imagens, a superfície, e não a linearidade, são os habitares de tais sentidos.

As mudanças fazem das linhas menos importantes do que as superfícies. Mas elas já não mais suprem as necessidades de um novo pensar. À linha e à superfície de Flusser, acrescentamos a interface, a responsável por dar forma à interação entre usuário e computador (ou seja, o mouse, teclado, tela do computador, etc), o que permite a interação com conteúdos em hipermídia. O prefixo de amplificação “hiper” fornece à “mídia” a noção de “para além”. É uma saturação do conceito de mídia. Nela, todas as mídias encontram-se em consonância para passar uma única mensagem. É o sonoro do rádio, o visual da televisão e as letras impressas dos livros que se unem na linguagem em que tudo é válido. Ela é uma configuração que permite o audiovisual e todo o tipo de grafismos ao hipertexto, que representa o texto fluido, reconfigurável à vontade, 
organizado alinearmente em arquiteturas reticuláveis (Santaella, 2005, p.24.), manuseável pela interface. A hipermídia não é um novo conceito, ela é experimentada há anos por meio das artes, por exemplo. Ou por meio de demonstrações científicas. Pois o próprio homem, em sua essência, é voz, texto e imagem, é hipermidiático. Porém, com o advento das tecnologias digitais, ela torna-se mais possível como formato, mais palpável como objeto.

A hipermídia permite motivar linhas não-determinadas, alinearidades, diversas superfícies sobrepostas, que traçam caminhos pela experiência direta do usuário com o conceito propriamente dito, o que acreditamos ser um passo mais próximo de uma interpretação hermenêutica dos processos da ciência, processo que começa com uma mudança do conceito de leitor e autor entre a era impressa e da cultura digital.

Para exemplificar essa ideia, Chartier (1998) cita a Bíblia em CD-ROM, em circulação na França. Por meio dela, o leitor passa a ter novos tipos de relação com o texto sagrado, que provavelmente foram mudando do rolo de papiro ao códex de pergaminho, até o livro moderno.

O leitor não é mais constrangido a intervir na margem, no sentido literal ou no sentido figurado. Ele pode intervir no coração, no centro. Que resta então da definição do centro. Que resta então da definição do sagrado, que supunha uma autoridade impondo uma atitude feita de reverência, de obediência, ou de meditação, quando o suporte material confunde a distinção entre o autor e o leitor, entre a autoridade e a apropriação? (Chartier, 1998, p.91).

A mudança de suporte é, portanto, muito mais do que apenas um formato, mas atua nas relações entre a obra e o leitor, autor e leitor, autor e obra, ou tudo isso simplesmente se confunde e já não podemos mais saber o que é do autor ou do leitor. O leitor-autor deixa de ser o receptor, tal como é denominado o telespectador da televisão ou do rádio, por exemplo. Trata-se agora de construção ativa, independente e autônoma do significado (Bairon, 2007, p.57). O que é a palavra de Deus, ou colocação humana. E isso já não importa mais...

No interior da Hipermídia como Comunicação Integrada como produção do conhecimento, o papel do autor deve ser profundamente revisto, transferindo, 
definitivamente, parte de seu poder e autoridade ao leitor, que estará ininterruptamente atrás de novos elos e, não, de uma única compreensão. Talvez não possamos mais falar em autoria, mas em paternidade de ambientes digitais de pesquisa. (Bairon, 2007, p.148)

Paternidade de ambientes digitais, nesse sentido, como a equipe realizadora do projeto hipermidiático. Uma equipe desfigurada, não relacionada a um único nome "provedor", de um “coordenador”, "idealizador”, mas uma equipe que trabalha em conjunto, cada um nas margens de seu próprio conhecimento na contribuição do todo, seja ele técnico, conceitual, metodológico. O que ainda se torna difícil de acontecer dentro dos parâmetros atuais de avaliação do trabalho acadêmico, que exige uma autoria nomeada, um autor-principal. Além disso, ainda temos a concepção atual da produção científica pelos próprios pesquisadores que querem, e precisam por questões de financiamento, ter pesquisas produzidas sob sua coordenação e altamente afinadas com suas próprias bibliografias e linhas de pesquisa.

Essa característica da pesquisa científica atual deve-se principalmente por termos construído nossa tradição sobre os parâmetros da cultura impressa. O texto impresso não é anônimo, ele sempre está ligado ao conhecimento de alguém específico, ou um grupo, a uma assinatura. O que não acontecia nas culturas de tradição oral: afinal, quem foram os autores das lendas populares que ouvimos de nossos avós desde crianças? Os ditados? As superstições? O digital, nesse sentido, mais uma vez se apresenta como um retorno a valores esquecidos pelo tempo, pelo arraigamento da forma de pensamento escrita. É o que Bairon (2007), com embasamento em Gadamer, anuncia:

O desafio de trabalhar o conteúdo informativo e/ou analítico nas mídias digitais não só implica enfrentar as tradicionais barreiras epistemológicas de ruptura entre imagem, texto, áudio, etc, mas, sobretudo, superar a dificuldade de desenvolver uma tradição adequada em uma estrutura hipertextual, sendo que enfrenta a resistência de um discurso conservador que acredita ter a escrita o único “dom” de produzir conhecimento. (Bairon, 2007, p.32)

Assim, a escrita representa apenas uma parte no todo da compreensão, que também deve considerar aquilo que é inexprimível pela matriz verbal do pensamento. Nesse sentido, 
compreendemos o método como uma forma limitadora do conhecimento e apontamos a margem do digital como uma abertura desse método. Mas na margem emerge a necessidade de repensarmos na questão das avaliações institucionais e na autoria do trabalho científico.

Bolter realça que nesse mutante espaço eletrônico, os escritores necessitarão de um novo conceito de estrutura unitária; deverão aprender a conceber seus textos como uma estrutura de possíveis estruturas. Para Bolter, o escritor deverá praticar uma espécie de escritura noutra dimensão, criar linhas coerentes que o leitor possa descobrir sem fechar, prematura ou arbitrariamente, nenhuma possibilidade. (Bairon, 2007, p.60).

Essa nova espécie de escritura pensada por Bolter é o que compreendemos pela hipermídia. Ela, ao trabalhar não apenas com a escrita, mas permitir o visual e o sonoro, e todas as combinações permitidas no âmbito das três matrizes, que inclui, por exemplo, a linguagem audiovisual, permite uma abertura a novas sensorialidades que levam a novas formas de compreensão, até então não abarcadas pela escrita pura. Em consonância com Gadamer (2008) e Bairon (2007), entendemos que a nossa percepção não é reflexo daquilo que foi proporcionado aos sentidos por um estímulo pré-determinado, o que significaria mais uma espécie de dogmatismo epistemológico. É a isso que se deve o método ao partir sempre de uma ciência normal, sem refletir sobre sua própria constituição histórica ou filosófica. A hipermídia permite que nos livremos da noção moderna de "imediatez" dos conceitos e nos permite repensá-los. Na comunicação hipermidiática,

Mais que o acontecer de uma simples interpretação, trata-se de um ambiente midiático que trabalha com a possibilidade de respeitar o tempo da espera, que pacientemente se coloca à disposição da compreensão ou da emergência de um sentido. Esperar, demorar e refletir não é perda de tempo, ao contrário, trata-se da hiperbolização da surra que a leitura dá na televisão tradicional. [...] A demora para compreender é fruto do desdobramento de uma relação dialógica que não tem prazo para terminar, pois seu sentido cronos primeiro é durar até que seja levado seu fim. (Bairon, 2010, p.24) 
Assim, a ciência encontra no digital um ambiente frutífero de desenvolvimento por meio da linguagem híbrida, imagética e conceitual, que leve a interações com qualquer outro sentido. É no ambiente hipermidiático que se possibilita a desconstrução hermenêutica das matrizes da linguagem e do pensamento.

Para Bairon (2007) estamos no momento da lide com a tecnologia, em que o saber deve acompanhar o fazer e o compreender. Dessa forma, compreende-se a criação digital em hipermídia como uma abertura à produção de novas formas de conhecimento, uma vez que permite uma multiplicação deste por meio de novas características. A partir disso, portanto, é possível prever e inferir uma real possibilidade de construção de conteúdos digitais em hipermídia que consigam efetivamente contribuir para que a ciência volte a ser reconhecida como parte integrante do processo social coletivo, uma vez que parte de conteúdos segmentados, possibilita processos de interação (e não mais o receptor passivo e alheio), o formato híbrido, de convergência das matrizes verbal, sonora e visual (Santaella, 2003), é um convite ao saber sensório, ao aprendizado verdadeiro, à imersão nos conceitos em sua essência ontológica.

\section{Ciência e senso comum - a convergência no digital}

Utilizamos aqui, como embasamento, o conceito de ruptura epistemológica, cunhado pelo epistemólogo e filósofo da ciência Gastón Bachelard. Segundo ele, a ciência apenas se constroi por meio de três atos epistemológicos fundamentais, sendo eles, a ruptura, a construção e a constatação. Esses três atos têm por função criar um distanciamento do homem com o objeto de estudo. É na ruptura que o cientista eleva-se diante daquele saber puro da observação e transforma-o em “algo mais”, nas palavras de Bachelard, (1996, p.29).

[O] espírito científico deve formar-se contra a Natureza, contra o que é, em nós e fora de nós, o impulso e a formação da Natureza, contra o arrebatamento natural, contra o fato colorido e corriqueiro. O espírito científico deve formar-se enquanto se reforma. Só pode aprender com a Natureza se purificar as substâncias naturais e puder em ordem os fenômenos baralhados.

A partir dessa noção, Boaventura de Souza Santos propõe a noção de dupla ruptura epistemológica Segundo essa concepção, a ciência continua sim a romper com o senso comum e a desenvolver postulados que levem a um desenvolvimento tecnológico ou social, mas, a partir 
disso sofrer uma nova ruptura. Ou seja, reconstruir essa ciência em forma de um novo discurso que a faça se transformar novamente em conhecimento comum, acessível e aberto ao diálogo, ao questionamento e ao debate.

[A] dupla ruptura procede a um trabalho de transformação tanto do senso comum como da ciência. Enquanto a primeira ruptura é imprescindível para constituir a ciência, mas deixa o senso comum tal qual estava antes dela, a segunda ruptura transforma o senso comum com bases na ciência. Com essa dupla transformação pretende-se um senso comum esclarecido e uma ciência prudente. (Santos, 1989, 41).

Sob a óptica da dupla ruptura epistemológica, Santos (1989) desenvolve a ideia de que para chegar a realizá-la a ciência precisaria submeter-se a três topoi aos quais a desconstrução hermenêutica da segunda ruptura deve passar, sendo eles: 1. O desnivelamento de discursos; 2. A superação da dicotomia contemplação/ação; e 3. A necessidade de instauração de um novo equilíbrio entre adaptação e criatividade. A dupla ruptura epistemológica desconstroi a ciência, inserindo-a em uma totalidade que a transcende. Uma desconstrução que não é ingênua nem indiscriminada porque se orienta para garantir a emancipação e a criatividade da existência individual e social, valores que só a ciência pode realizar, mas que não pode realizar enquanto ciência.

Uma comunidade científica pautada pela dupla ruptura epistemológica é maximamente intersubjetiva e tolerante. O conhecimento que produzirá não será "insensível" a esse fato. Será um conhecimento edificante, mais formativo do que informativo, tanto na contemplação, como na transformação do mundo, criador e não destruidor da competência social dos não cientistas, um conhecimento envolvido emocionalmente no alargamento e no aprofundamento da “conversação da humanidade” tal como concebem Dewey e Rorty. (Santos, 1989, p.118).

Ou seja, os três topoi rumo à hermenêutica da epistemologia são diretamente possibilitados pela hipermídia. Ao trabalhar com a noção de comentário prevê a participação de 
diversos discursos interagindo, sem hierarquia de poder: é a voz da ciência que se coloca em um patamar passível de discussão por outras formas de conhecimento. O leitor deixa de apenas contemplar, mas se permite discutir junto. Aí entra a ação, também por meio da interface do computador: é preciso manusear o mouse e navegar pelas telas para chegar ao conteúdo. Por fim, a criatividade que deve voltar à atividade do pesquisador: afinal, como reconstruir minha ciência dura de forma a atingir meu público? A utilização de vídeos, imagens, sons, a exploração de uma experiência estética são essenciais nesse sentido, e possibilitadas pela linguagem hipermídia.

Para melhor compreendermos a ideia de dupla ruptura epistemológica pela hipermídia vamos utilizar como exemplo o trabalho Diadorim- História Local nos Processos de Alfabetização de Crianças, Jovens e Adultos do Município de Diadema, uma hipermídia produzida por uma equipe de pesquisadores liderados pela Profa. Dra. Zilda Iokoi e pelo Prof. Dr. Sérgio Bairon no ano de 2002. O trabalho constitui-se de um ambiente hipermidiático em que se reconstruiu em 3D uma escola pública do município de Diadema, na região metropolitana de São Paulo. Dentro dessa escola o personagem Diadorim percorre os ambientes, podendo interagir com objetos que os levam a uma parte do conteúdo de história, partindo da história local do município e região para chegar a elementos da história geral do Brasil e do Mundo.

Essas histórias, contadas de forma literária e didática foram produzidas por pesquisadores da área de História, que partiram de teses e dissertações produzidas na Faculdade de Filosofia, Letras e Ciências Humanas (FFLCH/USP). Ou seja, o discurso acadêmico foi reconstruído de

forma a se criar uma narrativa passível de compreensão das crianças e que as levassem ao aprendizado do conteúdo da grade curricular de História. Isto é, a dupla ruptura epistemológica: primeiro rompeu-se com o senso comum transformando-o por meio do método científico, depois se reconstruiu o discurso de forma que se fizesse palatável a um público de crianças em fase de aprendizado.

A seguir vamos instrumentalizar os topoi de Santos em sua aplicação para a realização da dupla ruptura por meio da hipermídia.

\section{Diadorim e a dupla ruptura pela hipermídia}


O primeiro topos de Santos (1989) parte da noção de comentário desenvolvida por Michel Foucault. Nas vozes dele, "É sempre possível dizer o verdadeiro no espaço de uma exterioridade selvagem” (Foucault, 1996, p.35), mas complementa sobre a orientação que temos de compreender essa verdade somente nos discursos que seguem uma determinada política discursiva. Assim, entendemos a possibilidade de sempre reconstruir e redizer o mesmo discurso, fazendo-o atuar não apenas dentro de uma disciplina específica, mas a atingir também todos os tipos de público. É o que podemos chamar de “desnivelamento de discursos”.

Isso é praticado por toda sociedade que tenha por princípio comunicacional a linguagem. As palavras, mesmo quando ditas, podem ser reditas e sobre o que dizem sempre se terá algo a dizer o que concede ao discurso a possibilidade de sempre ser pronunciado novamente com outras formulações de palavras. Isso, na concepção de Foucault, ocorre por meio do que se denomina “comentário” que é, para ele:

Por ora, gostaria de me limitar a indicar que, no que se chama globalmente um comentário, o desnível entre texto primeiro e o texto segundo desempenha dois papéis que são solidários. Por um lado permite construir (e indefinidamente) novos discursos: o fato de o texto primeiro pairar acima, sua permanência, seu estatuto de discurso sempre reatualizável, o sentido múltiplo ou oculto de que passa por ser detentor, a reticência e riqueza essenciais que lhe atribuímos, tudo isso funda uma possibilidade aberta de falar. Mas, por outro lado, o comentário não tem outro papel, sejam quais forem as técnicas empregadas, senão o de dizer enfim o que estava articulado silenciosamente no texto primeiro. Deve, conforme um paradoxo que ele desloca sempre, mas ao qual não escapa nunca, dizer pela primeira vez aquilo que, entretanto, já havia sido dito e repetir incansavelmente aquilo que, no entanto, não havia jamais sido dito. A repetição indefinida dos comentários é trabalhada do interior pelo sonho de uma repetição disfarçada: em seu horizonte não há talvez nada além daquilo que já havia em seu ponto de partida, a simples recitação. O comentário conjura o acaso do discurso fazendolhe sua parte: permite-lhe dizer algo além do texto mesmo, mas com a condição de que o texto mesmo seja dito e de certo modo realizado. A multiplicidade aberta, o acaso são transferidos, pelo princípio do comentário, daquilo que arriscaria de ser dito, para o número, a forma, a máscara, a circunstância da repetição. O novo não está no que é dito, mas no acontecimento de sua volta. (Foucault, 1996, p.24-26). 
Segundo Landow (2006), no hipertexto, mesmo que não possamos mudar aquilo que está escrito, é possível escrever uma resposta, um comentário, afinal, para o que está produzido e linká-lo ao documento original. Isso permite a criação de caminhos individualizados de leitura: o texto que foi lido e comentado por diversas pessoas terá provavelmente uma forma diferente do original, que vai sugerir novas passagens, novas rotas de conhecimento (Landow, 2006). Essa noção de comentário relaciona-se diretamente com a "margem" que significa aqui a nãolinearidade do digital e todas as suas consequências. É na margem que se possibilita o processo hermenêutico de interpretação: localiza-se nas fendas presentes entre o discurso e o comentário, mas não se perde do discurso primeiro. Mesmo reconstruído, o trabalho científico continua ali. O comentário é recitação, ainda é, portanto, ciência.

O hipertexto circula nas margens e enfatiza que a margem tem muito a oferecer, tanto quanto ou mais do que o texto central. A centralidade, como a beleza e a relevância, encontra-se na mente do espectador.

This hypertextual dissolution of centrality, which makes the medium such a potentially democratic one, also makes it a model of society of conversation in which no one conversation, no one discipline or ideology, dominates or founds the others. It is thus the instantiation of what Richard Rorty terms edifying philosophy, the point of which "is to keep the conversation going rather than to find objective truth”. It is a form of philosophy ${ }^{3}$. (Landow, 2006, p.123).

Ou seja, hipertexto é um modelo em que a conversação é muito mais importante do que encontrar propriamente um fim racional objetivo. O conhecimento se forma por meio de diálogos que se cruzam e vão criando sentidos diferentes para cada leitor. Nesse sentido, o hipertexto permite e encoraja trabalhos colaborativos no mesmo sentido que encoraja abordagens interdisciplinares por meio da construção de materiais criados por especialistas em diferentes disciplinas que trabalham juntos, colaboram (Landow, 2006, p.123).

\footnotetext{
3 “Essa dissolução hipertextual da centralidade que faz o meio tão potencialmente democrático, também faz dele um modelo de sociedade da conversa em que nenhuma conversação, nenhuma disciplina ou ideologia, domina ou funda as outras. Essa é, portanto, a instanciação do que Richard Rorty chama de filosofia da edificação, cujo propósito é de 'manter a conversa em vez de encontrar a verdade objetiva'.”'
} 
Na obra Diadorim, o hipertexto faz as vezes do comentário. A diferença é que nela a escolha foi por transformar o texto científico original em comentário, e a narrativa reconstruída em trilha principal a ser seguida para chegar ao conhecimento. O trabalho científico primário, neste caso, enriquece a margem e dialoga com o navegador com níveis de escolaridade mais elevados, ou serve aos mais curiosos, sem deixar de falar àquelas crianças ainda no início do processo de aprendizagem. Nesse sentido, os hiperlinks construídos com base em relações conceituais dialógicas facilitam a expressão da multiplicidade de vozes (Bairon, 2007, p.113).

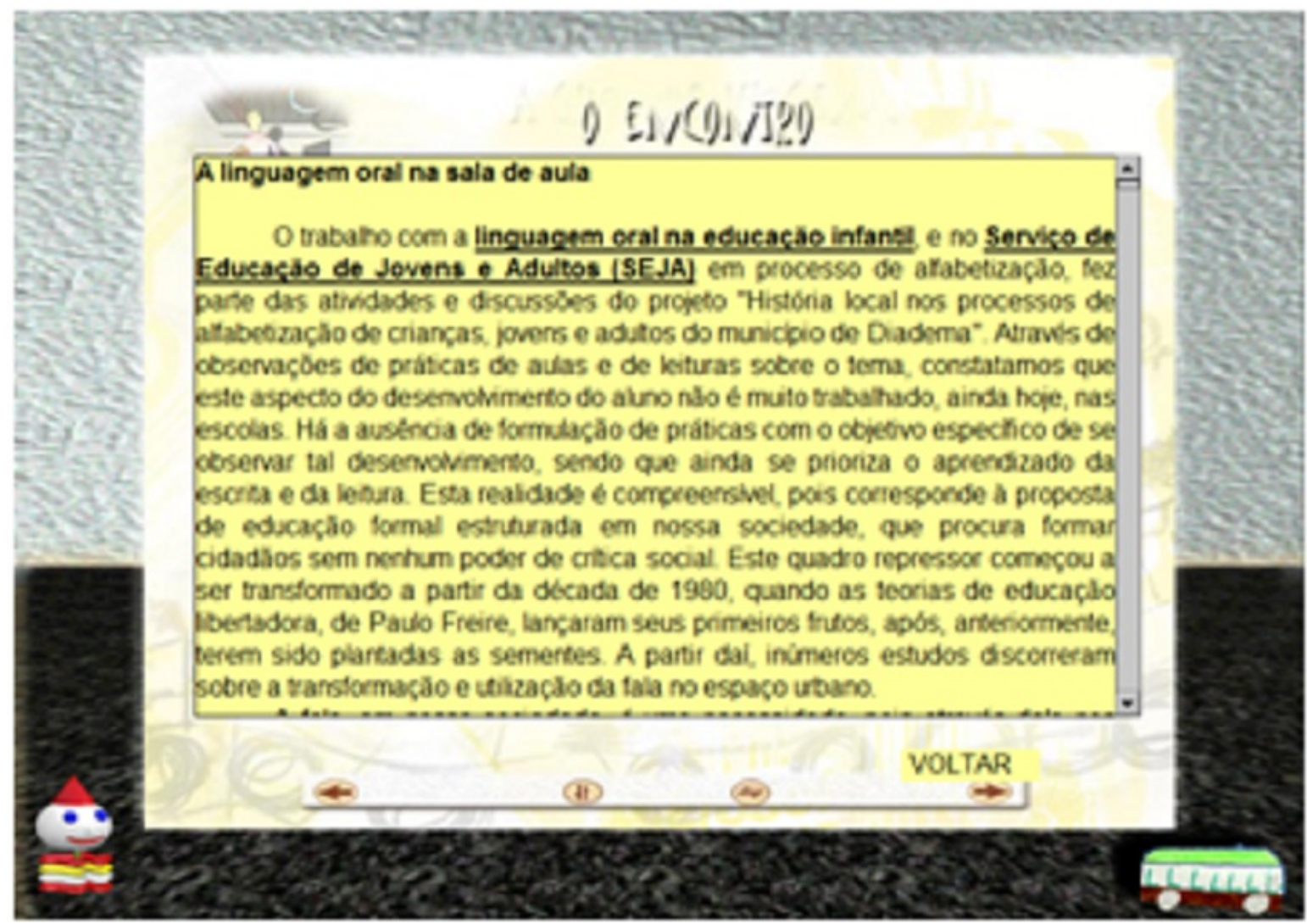

Figura 1. Texto voltado aos professores. Na hipermídia, textos voltados aos professores e às crianças integram o mesmo ambiente como comentários. A margem digital é utilizada em sua totalidade para abarcar todos os discursos passíveis de interação com o objeto. 


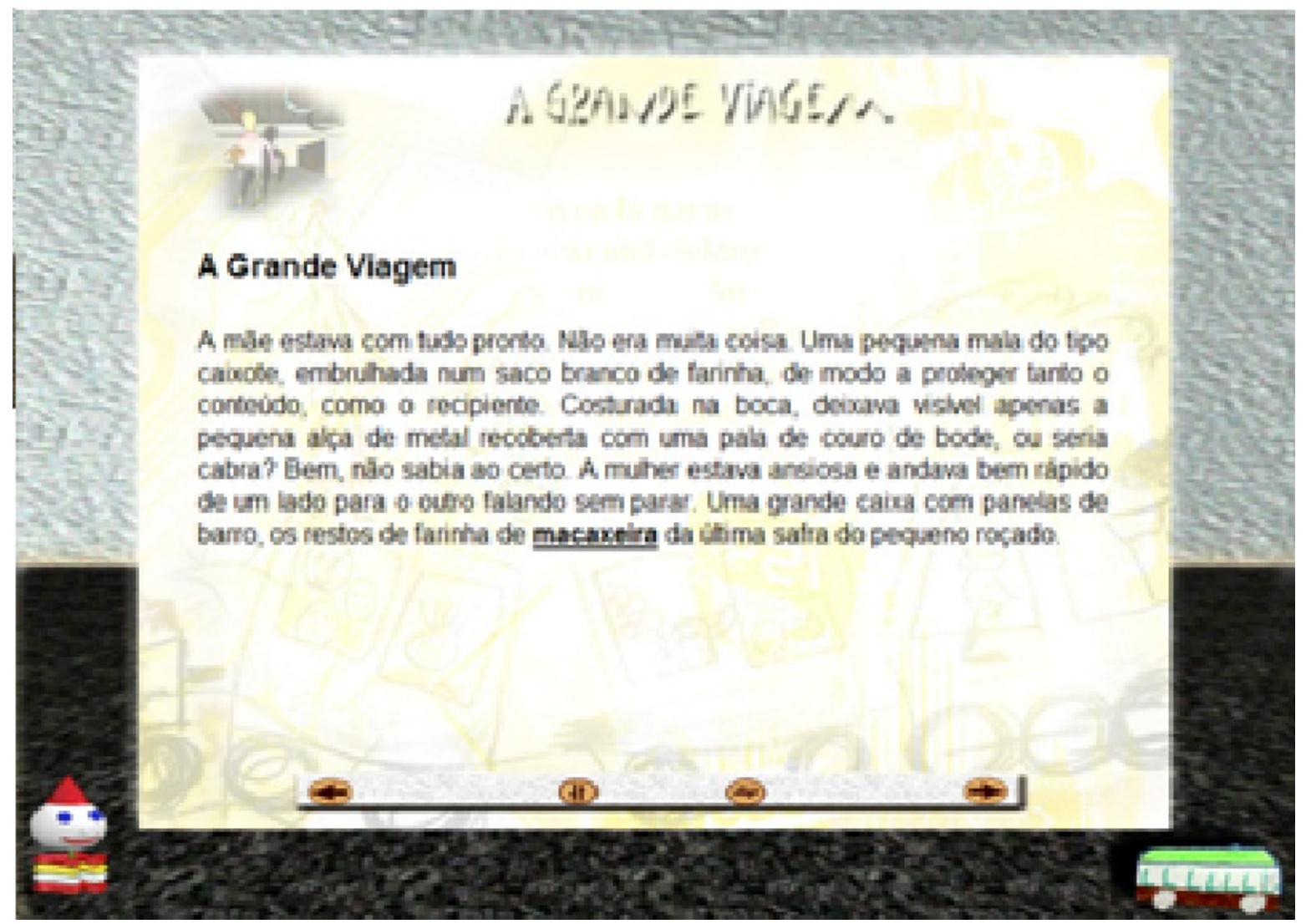

Figura 2. Reconstrução do texto científico primeiro para a produção de uma história educativa. As palavras grifadas levam ao hiperlink que as explica.

O texto primeiro, no caso da hipermídia Diadorim, é o texto científico: aquele que permanece, que nos guia. Mas sua mutabilidade para novos formatos, as reticências da hipermídia, como a criação de histórias narrativas; a inserção de novos materiais como recortes de jornais, entrevistas, desenhos produzidos pelas crianças, promovem o dizer algo além do discurso sem impedir que o texto mesmo seja dito ou realizado, como previu Foucault; a interface que permite uma interação direta das crianças com o personagem e com os diversos conteúdos escondidos no ambiente da escola; tudo isso confere ao discurso sentidos múltiplos e possui mais riquezas do que escancara. Segundo Bairon e Petry (2000), essa interatividade permite um ambiente em que o jogador sabe muito bem como jogar, mas não sabe exatamente o que sabe, fazendo-o levar a um conhecimento muito maior do que quando apresentamos a ele um caminho definido. A interatividade direcionaria o usuário ao que chamam de “reticularidade do mundo”.

$$
\text { ANIMUS } \begin{aligned}
& \text { Revista Interamericana de Comunicação Midiática } \\
& \text { E-ISSN 2175-4977 | v.12n.23 | } 2013 \text { | www.ufsm.br/animus }
\end{aligned}
$$


No caso de Diadorim o entorno da hipermídia é o próprio entorno do ser humano, das crianças que estudam na escola reconstruída no ambiente digital e revela uma possibilidade de compreensão pela exploração de um ambiente já familiar. O conhecimento espacial como conhecimento prévio leva a uma abertura maior do compreender por meio da interação do personagem com cada uma das atividades.

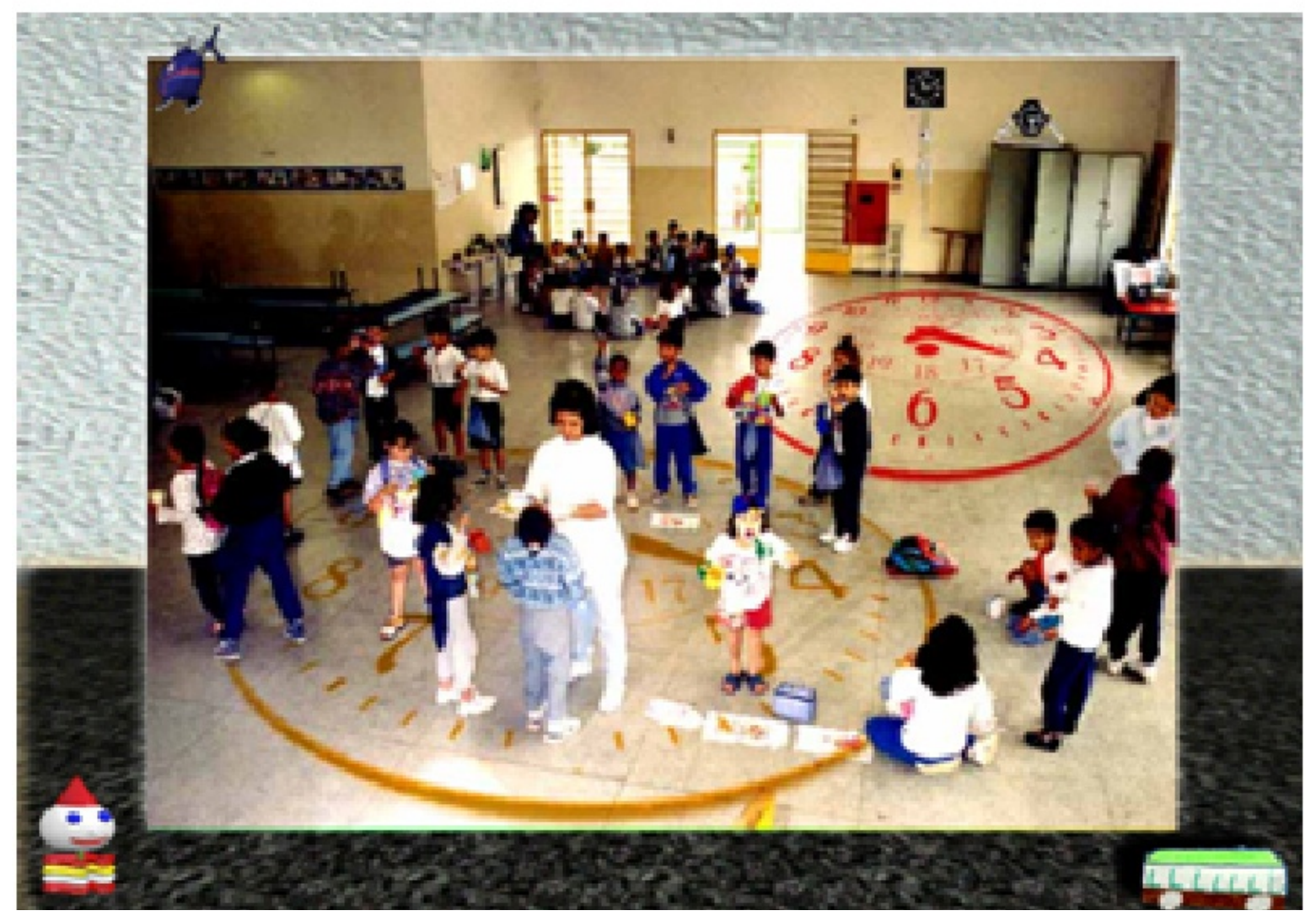

Figura 3. Inserção do cotidiano escolar na hipermídia por meio de fotografias, desenhos e sugestão dos professores. O entorno hipermidiático é o entorno do público para o qual o trabalho foi realizado.

Dessa forma compreendemos que a primeira condição de Santos (1989) foi contemplada por meio dos processos hipermidiáticos pela dupla ruptura. A noção de comentário, que abre a compreensões sobre a interatividade e o entorno da hipermídia, assim, pode contribuir para que a ciência passe pelo processo de desnivelamento de discursos por meio da promoção de um maior diálogo entre diferentes discursos, atenuando os desníveis que os separam. Desse modo, chegamos ao segundo topos que propõe a superação da dicotomia contemplação/ação. Nesse

$$
\text { ANIMUS Revista Interamericana de Comunicação Midiática }
$$

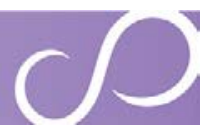


sentido propomos a discussão sobre a verdade e sua presença não apenas nos discursos produzidos pela ciência, mas também aos saberes do senso comum, na religião, na estética, etc.

É também nele [paradigma da ciência moderna] que as contradições da dicotomia mais claramente se manifestam. Por um lado, os critérios de verdade do conhecimento científico são interiores ao processo científico, e a única ação relevante a esse nível é a ação da investigação e da experimentação. Qualquer outro tipo de ação, nomeadamente a ação social, é exterior ao conhecimento, constitui tão-só o campo da sua aplicação, é, em suma, tecnologia. (Santos, 1989, p.43).

O que significa que no âmbito da ciência moderna a prática interior aos processos científicos é resumida à tecnologia que dela provém. Logo, o que se tem é uma relação da sociedade com a ciência que passa exclusivamente pela compreensão de uma práxis como tecnologia, que pressupõe uma teoria e uma técnica desconhecidas. Na dupla ruptura propõe-se emergir uma nova relação entre teoria, técnica e práxis, levando a um todo do compreender científico.

Nesse sentido da ação não podemos dizer que Diadorim contribua para uma maior compreensão da ciência como promotora da técnica, uma vez que o saber histórico possui, geralmente, pouca relação com processos de criação tecnológica, que são muito mais associados a ciências da engenharia, por exemplo. A técnica na hipermídia é um instrumento, e não um fim. Mas quanto mais desenvolvida a técnica, melhores os resultados na contemplação de uma teoria e uma práxis hipermidiática. Mas é possível estabelecermos um paralelo por meio da conceituação primária das noções de contemplação e ação.

Na filosofia grega contemplação era denominada teoria, que era diretamente oposta à práxis, ou ação. Assim, a vida de contemplação dos sábios era aquela que nos levava à teoria; e a vida ativa, era aquela relacionada àqueles que atuavam nas tarefas práticas do dia a dia. É nesse momento que chegamos ao problema de Rousseau de separação entre os saberes teóricos e práticos, que reaproxima a práxis do saber científico. Nesse sentido, os saberes contemplativos da ciência foram alçados ao patamar de verdade, e os saberes populares, da vivência, as lendas e notícias da comunidade, meramente acontecimento. 


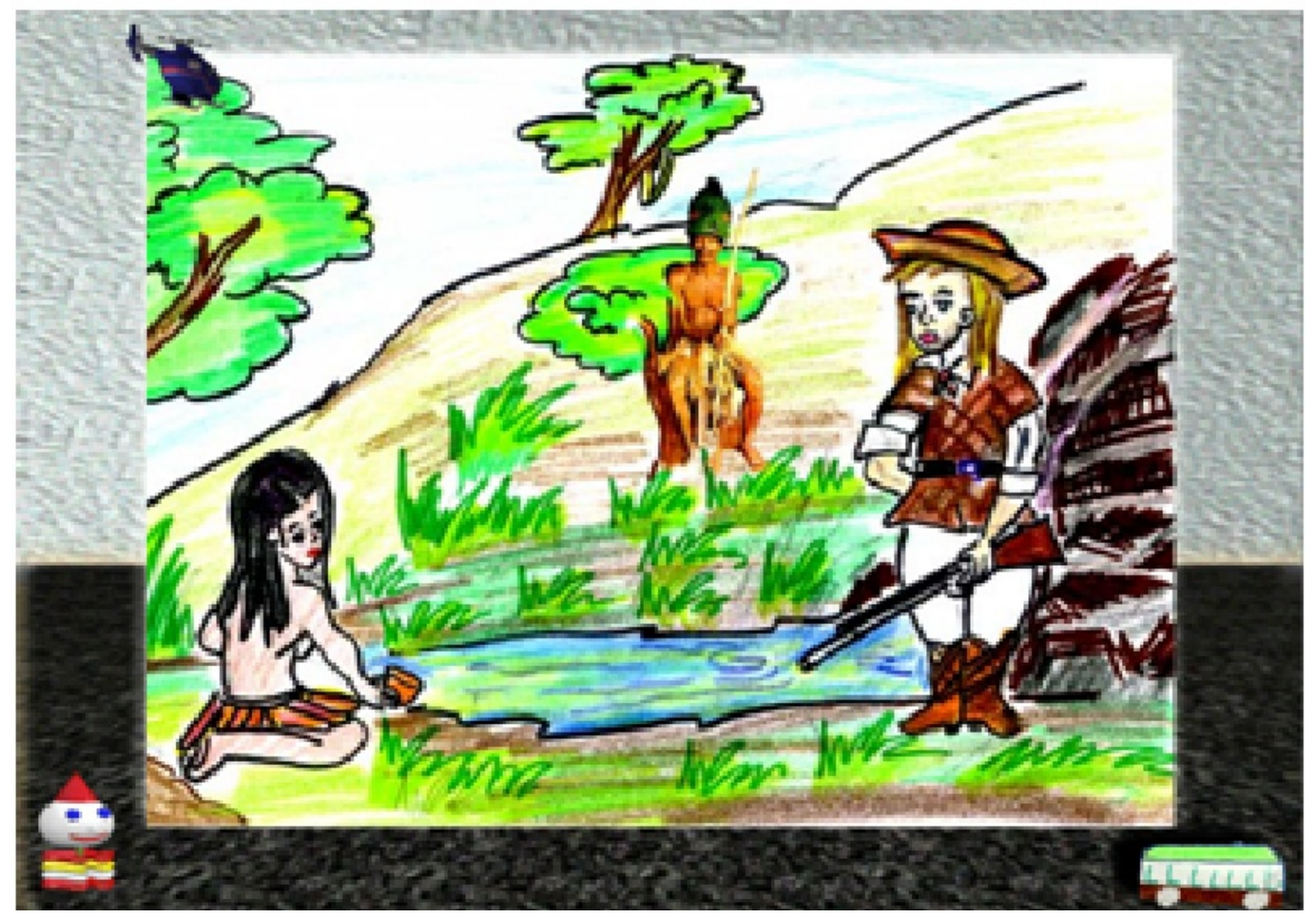

Figura 4. Ao partir de lendas indígenas conhecidas na região do $\mathrm{ABC}$, as crianças são levadas ao conhecimento científico. O conhecimento da ciência acontece como caminho tateado entre aquilo que é facilmente reconhecível pelo cotidiano da comunidade, até se atingir o conhecimento acadêmico.

Para que se promova a dissolução do saber científico novamente no senso comum, é preciso relacioná-lo a esses saberes da prática, inerente ao homem ordinário, ou seja, superar a dicotomia estabelecida entre o ato contemplativo relacionado ao cientista e a ação relacionada ao homem ordinário. Todos os homens, em maior ou menor grau, possuem vida cotidiana (Heller, 2008), prática, e uma possibilidade latente de relação com saberes científicos. Se considerarmos a própria noção de tecnologia da ciência, é possível partir de um aparelho tecnológico com o qual um indivíduo tenha contato e fazê-lo alcançar por meio dele o conhecimento científico associado à teoria ou à técnica científicas. Em Diadorim, esse aspecto é fortemente explorado por meio do conceito de "história local”. Assim, ao partir de um local já conhecido, de uma música, uma lenda da região, uma personalidade da população, foi possível criar conexões até chegar à história

$$
\text { ANIMUS } \begin{aligned}
& \text { Revista Interamericana de Comunicação Midiática } \\
& \text { E-Issn 2175-4977 | v.12n.23 | } 2013 \text { | www.ufsm.br/animus }
\end{aligned}
$$

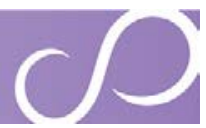


geral ou a aspectos mais específicos das pesquisas acadêmicas. Também foi possível explorar esses aspectos por meio de fotografias e canções hiperlinkadas aos textos principais.

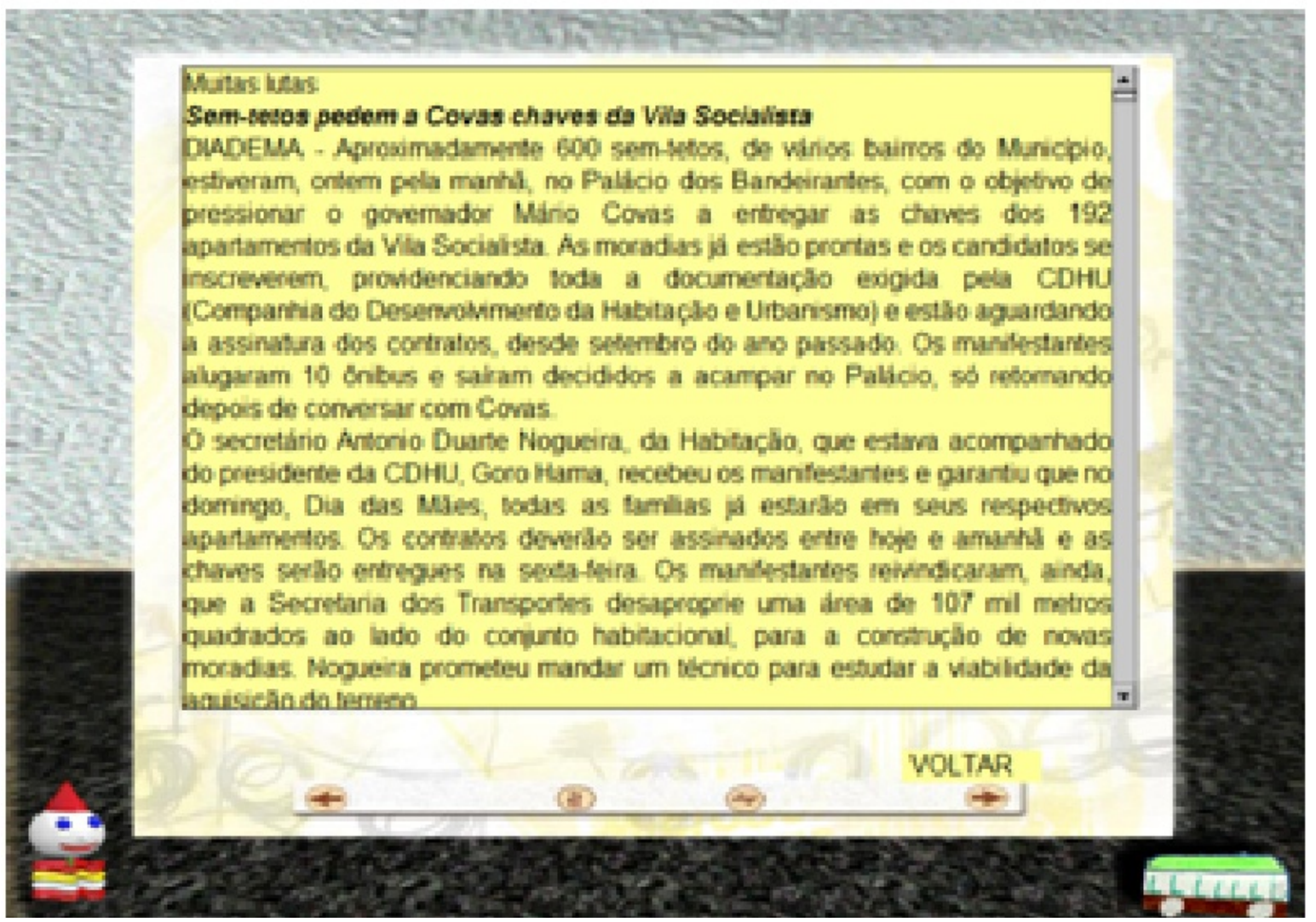

Figura 5. Hiperlinks de notícias da época. 


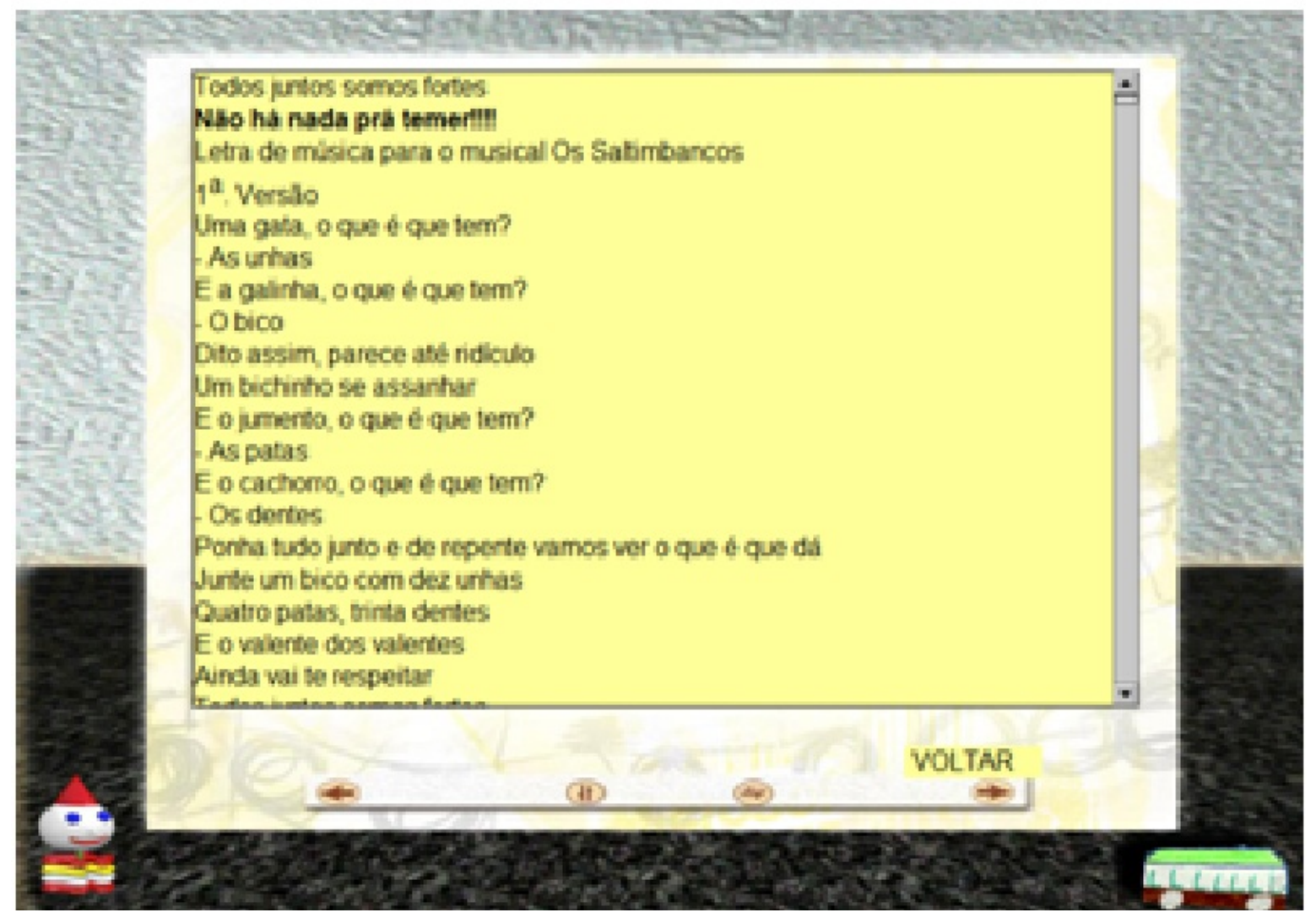

Figura 6. Letra de música.

Já o último topos diz que é necessário criar um novo equilíbrio entre adaptação e criatividade. Segundo Santos (1989) a produção técnica da natureza e do meio ambiente, bem como as tecnologias sociais que se foram acumulando para conformar o nosso cotidiano a níveis cada vez mais profundos, criou dependências múltiplas para o indivíduo ou grupo social, o que tornam difíceis a conquista e a preservação da identidade pessoal e social, o que nos fez desenvolver muito mais um poder adaptativo em detrimento de um poder criativo. Para o autor, é preciso recuperar a criatividade como elemento não apenas para alcançar a irracionalidade, mas também para atingir processos racionais de produção do conhecimento, que dê suporte a uma ciência mais acessível. Isso é possível uma vez que os processos racionais são indissociáveis dos irracionais.

Feyerabend (2010) aborda a noção de conhecimento instintivo de Mach. Segundo ele, o instinto faz um pesquisador formular princípios gerais sem necessariamente tirá-los de 
experimentos empíricos e isso seria o resultado de um longo processo de adaptação. Tiramos do nosso cotidiano uma série de decepções, aprendizagens, expectativas atingidas ou não, por meio das quais mudamos nosso comportamento e nossa mente contém os resultados dessa mudança. Esse aprendizado não é superado por experimentos empíricos objetivos, corrigidos instintivamente pela experiência do cientista.

O ser humano, segundo Feyerabend (2010), não é dotado de nenhum tipo de “alma” ou coerência e articulação corporais que o leva a atos criativos, mas isso é substituído pela forma como esse ser humano está colocado em seu ambiente.

Enquanto a concepção moderna separa o ser humano do mundo de uma maneira que faz com que a interação seja um problema insolúvel (tal como o problema mente-corpo), um guerreiro ou um poeta homérico não é nenhum estranho no mundo e compartilha muitos elementos com ele. Ele pode não "agir" ou "criar" no sentido dos defensores da responsabilidade individual, do livre-arbítrio, e da criatividade- mas ele não precisa desses milagres para participar das mudanças que o rodeiam (Feyerabend, 2010, p.168). 


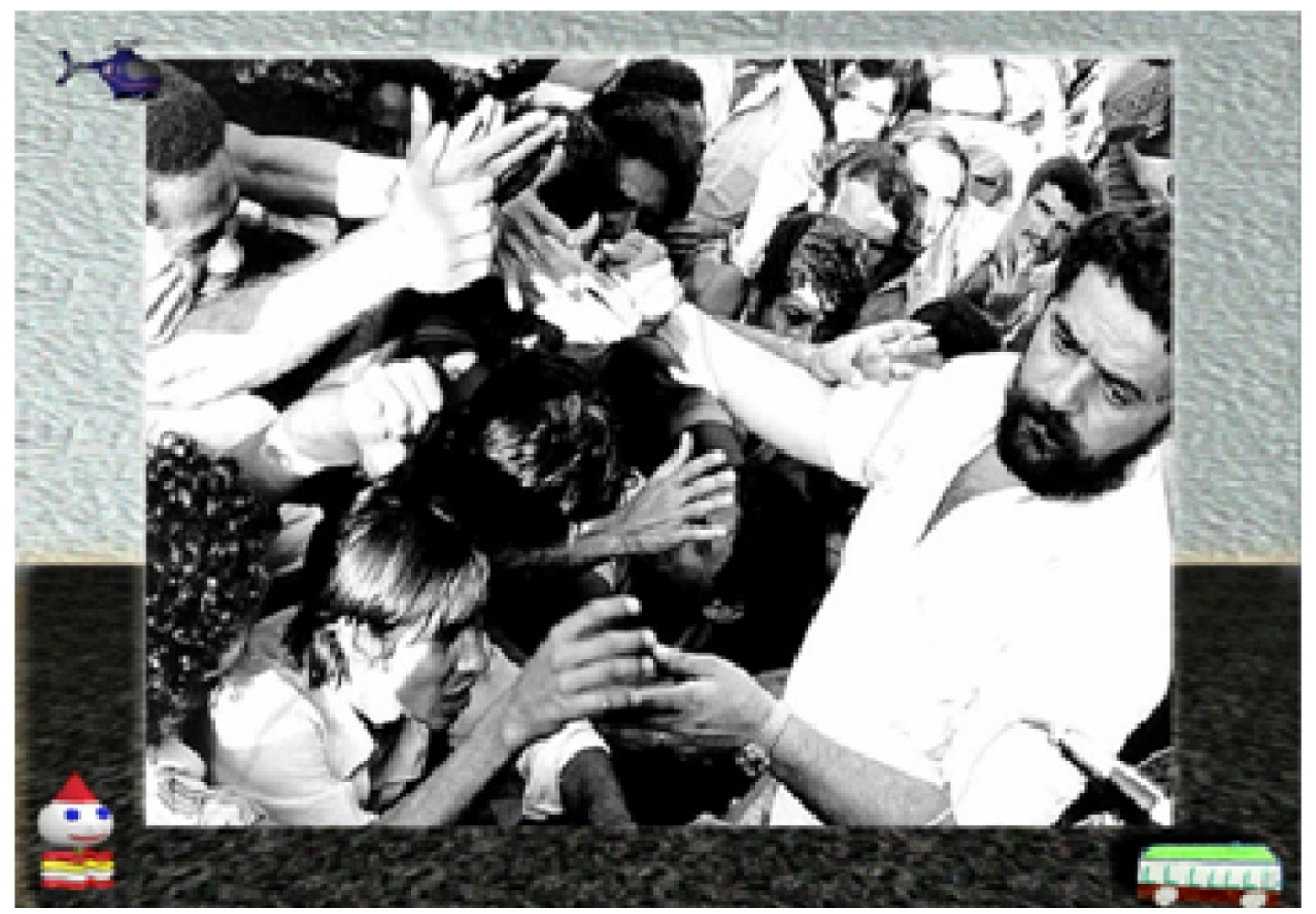

Figura7. O homem é também o mundo que o rodeia. O mundo compartilha elementos com o homem, e o homem participa das mudanças que o rodeiam.

Utilizar recursos da hipermídia exige que saibamos relacionar processos criativos aos conceituais: para criar o significado não basta mais criar uma narrativa com início meio e fim, mas é preciso fazer inferências, criar múltiplos caminhos por onde o navegador caminhar, permitir possibilidades de relações até então não pensadas. É preciso pensar no entorno da programação, prever o aleatório, criar um conceito estético próprio que leve ao compreender da experiência científica. Segundo Feyerabend (2010), a criatividade é considerada hoje em dia um dom especial, mas isso causou problemas na transição de conceitos complexos e concretos para conceitos simples e abstratos: os primeiros objetivos, separados daqueles que o produziam e das situações em que eram produzidos, 
[...] incapazes a princípio de fazerem justiça ao rico padrão de interações que é o mundo. É preciso um milagre para preencher o abismo sujeito e objeto, Homem e Natureza, experiência e realidade que é o resultado dessas "revoluções" conceituais- e a criatividade que leva a castelos maravilhosos de pensamento (filosóficos e/ou científicos) supostamente é esse milagre. Assim, a visão de mundo supostamente mais racional que já existiu só pode funcionar se for combinada aos eventos irracionais existentes, isto é, os milagres. (Feyerabend, 2010, p.169).

Não há mundo “objetivo” e "subjetivo” e não devemos mantê-los separados. Isso foi uma invenção da situação moderna: "não há nenhuma entidade monolítica a "ciência" a qual podemos dizer que colide com as coisas e a "situação moderna" é uma catástrofe que ofende nossos desejos mais fundamentais por paz e felicidade” (Feyerabend, 2010, p.170).

Por fim, Feyerabend diz que o ofício da ciência precisa recuperar a eficiência, a modéstia e a humanidade e admitir que os cientistas são cidadãos, não seres humanos dotados de uma criatividade sobrenatural que os fazem reconstruir a Criação. Cientistas devem retomar a condição de cidadão e, mesmo no domínio de sua especialidade, devem estar sujeitos a orientação e supervisão de seus concidadãos. E a dupla ruptura epistemológica aponta para esse caminho, uma vez que coloca a ciência à prova diante do cidadão participante do entorno científico, o que pôde ser observado em Diadorim. 


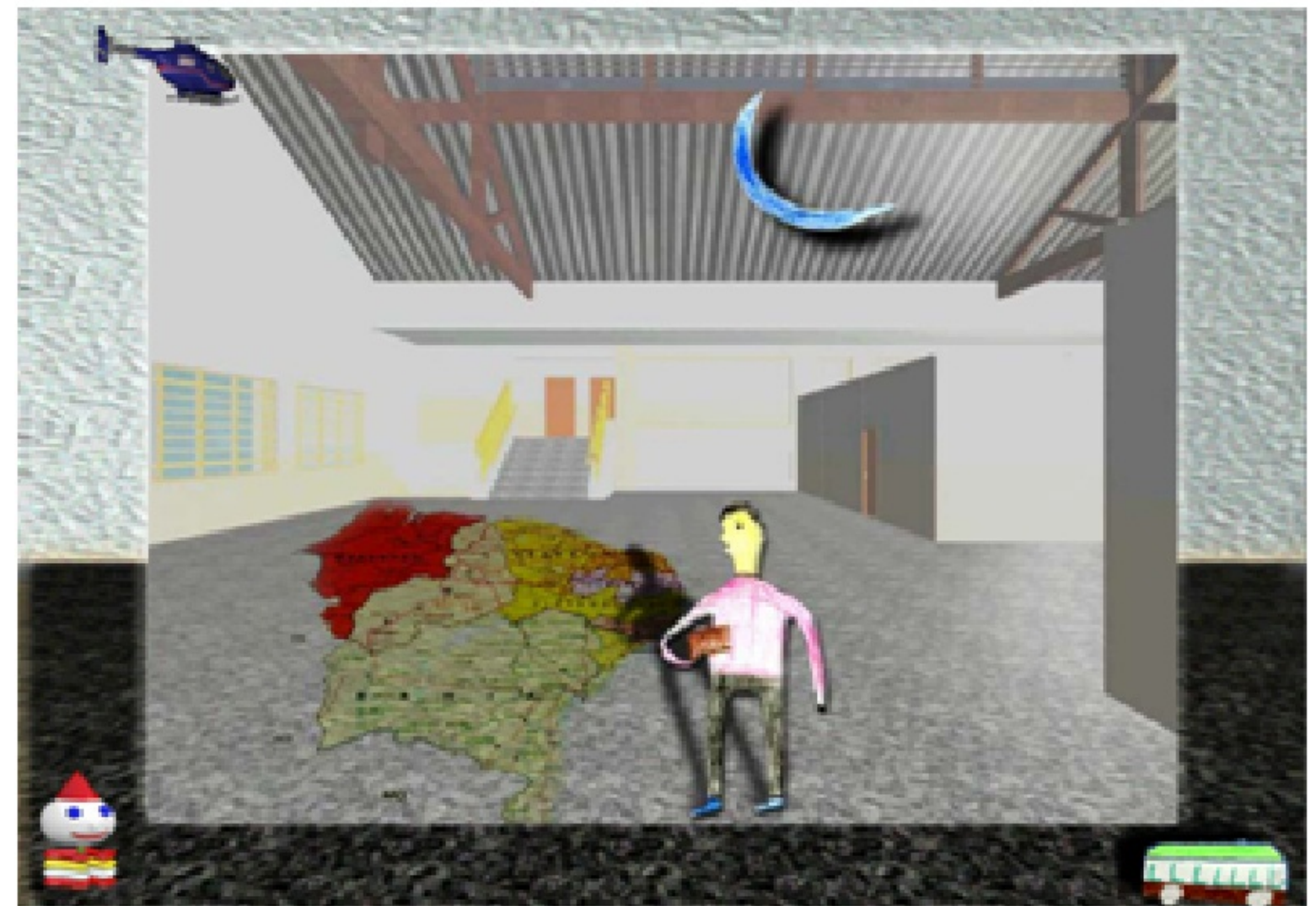

ANIMUS Revista Interamericana de Comunicação Midiática E-ISSN 2175-4977 | v.12 n.23 | 2013 | www.ufsm.br/animus 


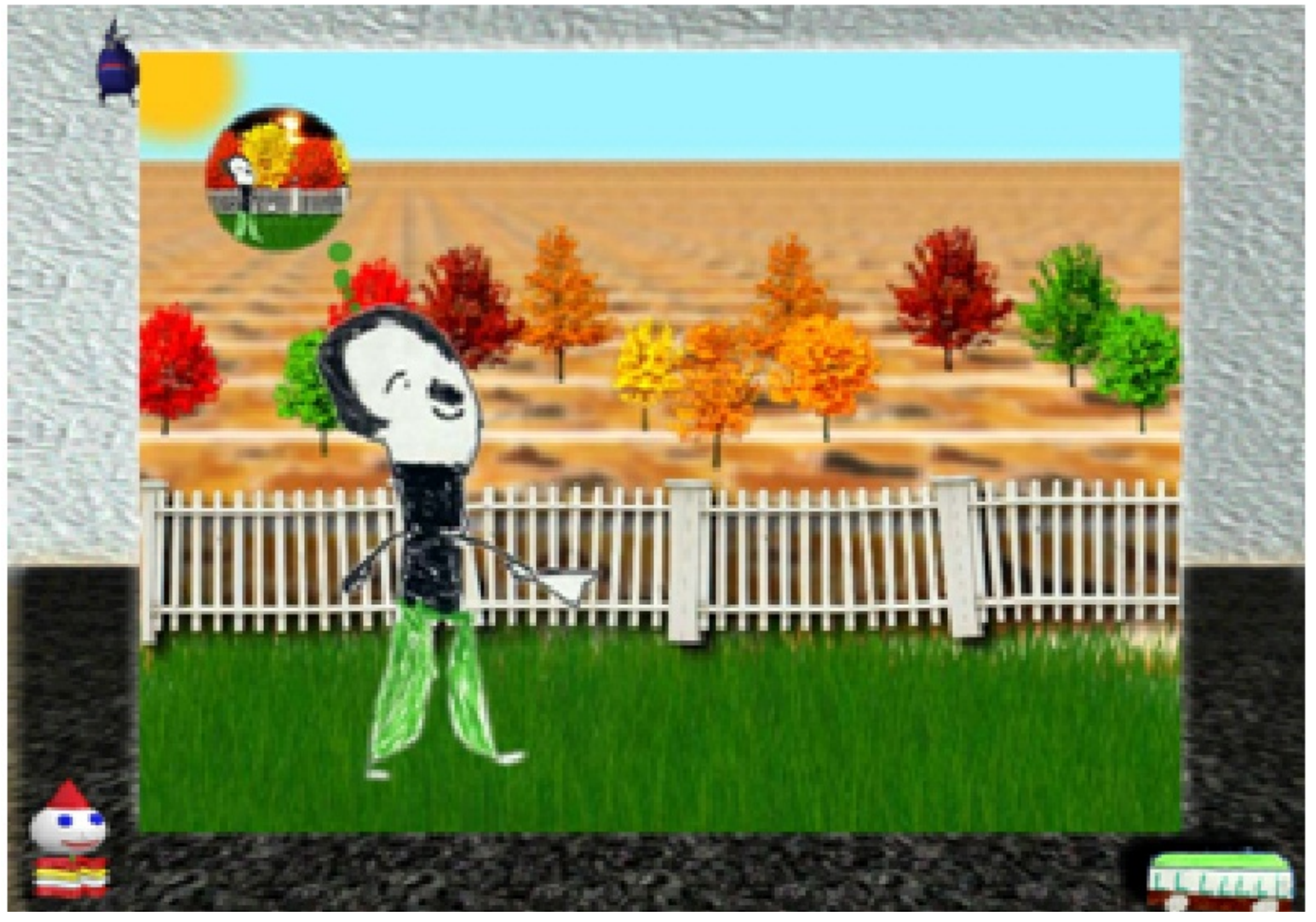

ANIMUS Revista Interamericana de Comunicação Midiática E-ISSN 2175-4977 | v.12 n.23 | 2013 | www.ufsm.br/animus 


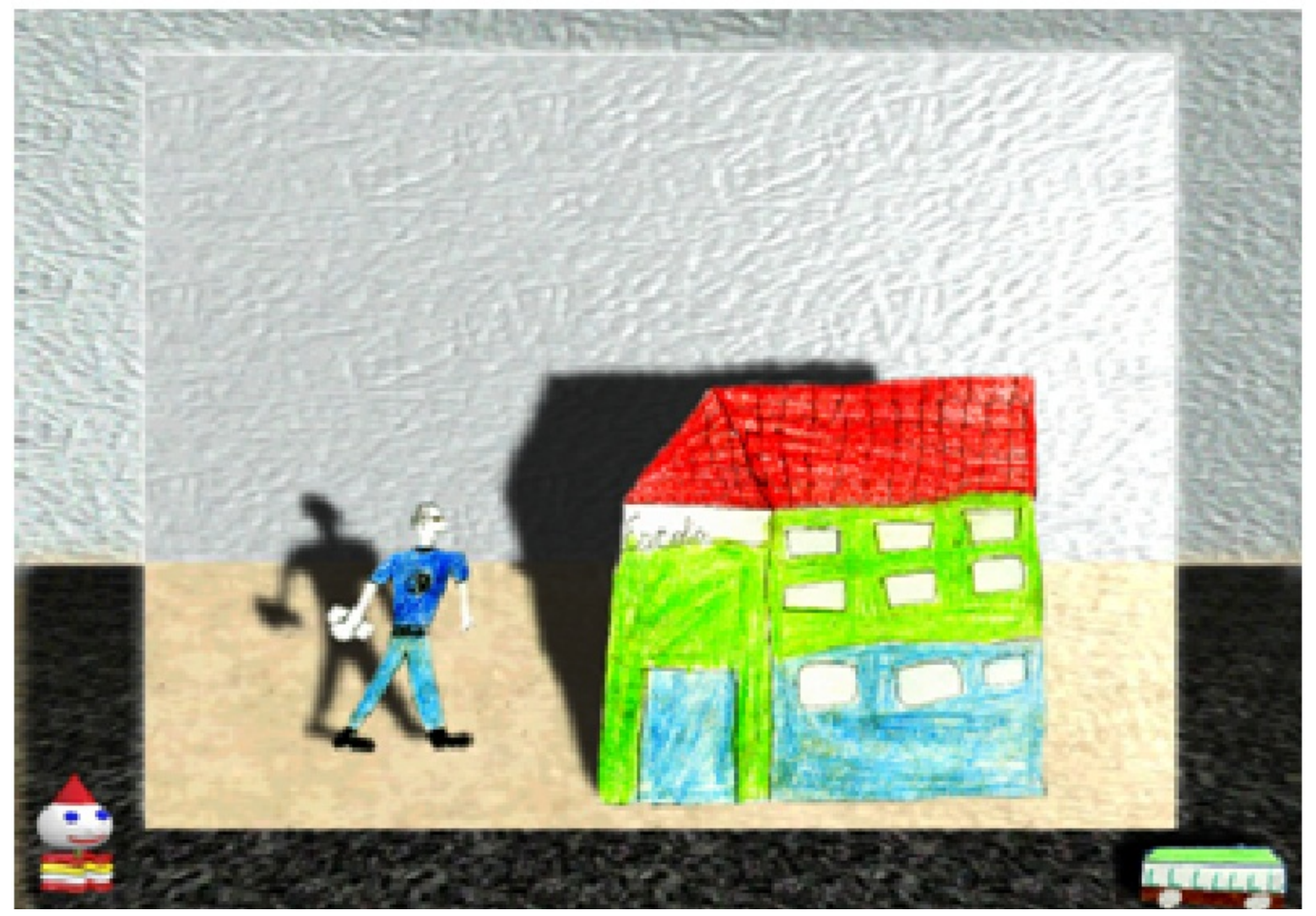

Figura 8, 9 e 10. Três interpretações de Diadorim pelas crianças. Na hipermídia o personagem "Diadorim” é representado de diversas formas diferentes por meio do desenho. Cada criança, ao ouvir as histórias do menino, imaginou-o de um jeito e desenhou o imaginado, interpretou-o segundo suas próprias referências. Em cada historinha Diadorim tem, portanto, uma forma diferente, sem modificar a significação do personagem. A experiência estética, assim, deu margens à interpretação individual sem perder o princípio original do discurso.

\section{CONSIDERAÇÕES}

A ciência pós-moderna caminha para uma nova relação entre ciência e senso comum, afinal, a ciência não representa as luzes completas, e nem o senso comum se fecha na ignorância.

Tal como sucede com os obstáculos epistemológicos, a dupla ruptura não significa que a segunda neutralize a primeira e que, assim, se regresse ao status quo ante, à situação anterior à primeira ruptura. Se esse fosse o caso, regressar-

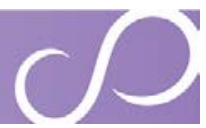


se-ia ao senso comum e todo o trabalho epistemológico seria em vão. Pelo contrário, a dupla ruptura procede a um trabalho de transformação tanto do senso comum como da ciência. Enquanto a primeira ruptura é imprescindível para constituir a ciência, mas deixa o senso comum tal como estava antes dela, a segunda ruptura transforma o senso comum com base na ciência. Com essa dupla transformação pretende-se um senso comum esclarecido e uma ciência prudente... (Santos, 1989, p.41).

Segundo o autor, no plano metodológico, a dupla ruptura manifesta-se ao responder a duas perguntas: a primeira, referente à ruptura bachelardiana, “o que é ciência?”; e a segunda “como é que a ciência se confirma a transformar-se em um novo senso comum?”, referente à hermenêutica da epistemologia. Dessa forma, a segunda ruptura passa a dar sentido à primeira, "pois a ciência só pode saber como se faz (contra o senso comum) se souber o que pode fazer (transformar o senso comum, transformando-se em senso comum)" (Santos, 1989, p.50). Isso só é possível acontecer uma vez que ciência e senso comum partem ambas do mesmo ponto, que está intimamente relacionado à sociedade para a qual se voltam. Nesse contexto, a epistemologia bachelardiana não será abandonada, mas apenas relativizada em torno de uma racionalidade envolvente.

A apropriação da comunicação digital para a efetivação dessa ciência pós-moderna, assim acreditamos, trabalha pela produção de uma ciência que não busca em momento algum romper-se com o senso comum, mas dialogar o tempo todo com ele para poder se construir. Na epistemologia hipermidiática não se fala em ruptura, mas em produção dialógica do conhecimento entre senso comum e ciência, sem que um precise romper com o outro para se desenvolver sozinho. Nesse modelo de produção científica a separação homem comum/cientista, sendo o homem comum como ignorante e o cientista como detentor do saber, não existe. Há, sim, uma diferenciação entre aquele que se forma e se propõe a produzir ciência, e aquele que não. Mas não há hierarquização de discursos. 


\section{REFERÊNCIAS}

BACHELARD, Gaston. A Epistemologia. Tradução de Fátima Godinho. Lisboa: Editora 70, 1971.

A formação do espírito científico: contribuição para uma psicanálise do conhecimento. Tradução de Estela dos Santos Abreu. Rio de Janeiro: Contraponto, 1996.

BAIRON, Sérgio. A hipermídia como comunicação integrada e a retomada da experiência estética na produção do conhecimento. Tese (Livre docência). Escola de Comunicações e Artes, Universidade de São Paulo, São Paulo, 2007.

. A comunicação das esferas, a experiência estética e a hipermídia. In: Revista USP/ Coordenadoria de Comunicação Social, Universidade de São Paulo. n.86. (jun/jul/ago 2010). p. 16-27. São Paulo: USP, 2010.

CHARTIER, Roger. A aventura do livro: do leitor ao navegador. Tradução de Reginaldo Carmello Corrêa Moraes. São Paulo: Imprensa Oficial do Estado de São Paulo / Editora Unesp, 1998.

CORRÊA, Elisabeth Saad. Fragmentos da cena cibercultural: transdisciplinaridade e o "não conceito". In: Revista USP/ Coordenadoria de Comunicação Social, Universidade de São Paulo. n. 86. jun/jul/ago. 2010. p. 6-15. São Paulo: USP, 2010.

FEYERABEND, Paul K. Adeus à razão. Tradução de Vera Josceline. São Paulo: Editora Unesp, 2010.

FLUSSER, Vilém; CARDOSO, Rafael (org.). O mundo codificado: por uma filosofia do design e da comunicação. Tradução de Raquel Abi-Sâmara. São Paulo: Cosac Naify, 2007.

FOUCAULT, Michel. A Arqueologia do Saber. 6. ed. Rio de Janeiro. Forense Universitária, 2002.

A ordem do discurso: aula inaugural no Collège de France, pronunciada em 2 de dezembro de 1970. Tradução de Laura Fraga de Almeida Sampaio. 19. ed. São Paulo: Edições Loyola, 1996.

. As palavras e as coisas. ed. 9. São Paulo: Martins Fontes, 2007.

GADAMER, Hans Georg. Verdade e Método I. Tradução de Flávio Paulo Meurer.. 10. ed. Petrópolis, RJ: Vozes, 2008. [para as referências foi utilizada a paginação brasileira]. 
GALISON, Peter; MOSS, Robb. Wall of Science. In: LATOUR, Bruno (org.); WEIBEL, Peter (org.). Making Things Public: atmospheres of democracy. Cambridge: MIT Press, 2005. p. 332-334.

HELLER, Agnes. O cotidiano e a história. Tradução de Carlos Nelson Coutinho e Leandro Konder. São Paulo: Paz e Terra, 2008.

HUXLEY, Aldous. Admirável Mundo Novo. Círculo do Livro. Rio de Janeiro: Editora Globo, 1932.

IOKOI, Zilda Márcia Grícoli; BAIRON, Sérgio. Diadorim: História Local dos Processos de Alfabetização de Crianças, Jovens e Adultos do Município de Diadema. Fapesp/USP/Secretaria da Educação de Diadema, 2002.

LANDOW, George P. Hipertext 3.0: critical theory and new media in an era of globalization. 3. ed. Baltimore: The John Hopkins University Press, 2006.

MCLUHAN, Marshall. Os meios de comunicação como extensão do homem. Tradução de Décio Pignatari. Editora Cultrix: São Paulo, 1964.

SANTAELLA, Lúcia. Culturas e artes do pós-humano: da cultura das mídias à cibercultura. São Paulo: Paulus, 2003.

. Matrizes da Linguagem e Pensamento: sonora, visual, verbal: aplicações na hipermídia. 3. ed. São Paulo: Iluminuras- FAPESP, 2005.

Paulus, 2004.

. Navegar no ciberespaço: o perfil cognitivo do leitor imersivo. São Paulo:

SANTOS, Boaventura de Souza. Introdução a uma ciência pós-moderna. Rio de Janeiro: Graal, 1989. 
Original recebido em: 30/04/2013

Aceito para publicação em: 20/07/2013

Érica Masiero Nering

Mestra e Doutoranda em Ciências da Comunicação pela Escola de Comunicação e Artes da Universidade de São Paulo (ECA-USP). Graduada em Comunicação Social pela Universidade Estadual Paulista "Julio de Mesquita Filho". 